\section{An explanatory sequential study on teaching strategies and communicative competence in online distance learning among grade 11 learners in the division of Cavite}

\author{
Calma, R-G-Lyn $\bowtie$ \\ Laguna College of Business and Arts, Philippines (rglyn.calma@deped.gov.ph)
}

Received: 23 July 2021

Available Online: 2 August 2021
Revised: 31 July 2021 DOI: $10.5861 /$ ijrse.2021.a028

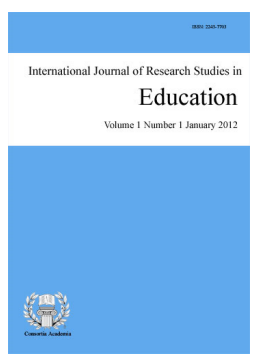

ISSN: 2243-7703 Online ISSN: 2243-7711

OPEN ACCESS

\title{
Abstract
}

The main thrust of this study was to assess level of manifestation of communicative competence among Grade 11 learners utilizing synchronous and asynchronous e-learning in selected public senior high schools in District of Silang, Division of Cavite. As an output, an ODL Language Teaching Framework is proposed. This study followed the sequential explanatory mixed method design. Through simple random sampling, the respondents of the study were 7 Master Teachers, 23 English Teachers and 450 Grade 11 learners from the aforesaid local. Meanwhile, through purposeful sampling, 7 Grade 11 English Teachers were selected as participants. Validated researcher-made survey instrument, modified pen and paper test derived from the MSA Reviewer and semi-structured interview questions were used for gathering of data. The mean, four-point Likert Scale, t-test, and Chi-squared were used as statistical treatment for quantitative data. The findings revealed that there was significant difference on the assessments of the Master Teachers and Grade 11 English teachers on the level of manifestation of the teaching strategies in developing communicative competence which might be due nature of work of the aforesaid respondents. Moreover, the finding also revealed that there was no significant relationship on the level of manifestation of teaching strategies and the level of Grade 11 learners' level of communicative competence. Using interpretative phenomenological analysis, divergent themes emerged from the responses of the participants. In synchronous e-learning, Real-Time Communicative E-Learning Activities and Rubrics as Effective Communicative Assessment Tool emerged. On the other hand, Self-Paced Method as Communicative Assessment Tool and Learner's Capability as Center of E-Learning Endeavors transpired from the responses regarding asynchronous e-learning.

Keywords: teaching strategies, communicative competence, online distance learning 


\section{An explanatory sequential study on teaching strategies and communicative competence in online distance learning among grade 11 learners in the division of Cavite}

\section{Introduction}

Over the past decades, developing communicative competence has been one of the challenges when it comes to language teaching. Globally, foreign researchers conducted various studies which highlighted the low communicative competence of some countries which are using English as Second Language such as Korea, Japan, China, Vietnam as well as Philippines.

The problem with regard the communicative competence among Senior High School Students was evident in the latest National Achievement Test (NAT) 2018 Result in the Division of Cavite where they got 40.37\% MPS in language and communication competencies. Quarter of these population were from the District of Silang, Division of Cavite. Recognizing the problem with communicative competence among learners, numerous studies were piloted where innumerable strategies and methods were utilized. In the study conducted by Ahmed \& Pawar (2018), they concluded that mastery of the communicative competence in English is an aim that learners struggle to achieve. There are several learning strategies and activities that are usually selected for enhancing language learning. These activities that enhance language learning are usually communication-based activities and task-based activities. But the utilization of these communication-based activities and task-based activities could not be possible due to the outbreak of COVID-19 Pandemic. To continue education amidst the crisis, the Department of Education has employed education through Distance Learning which includes Online Distance Learning or E-Learning.

Based from this situation, the researcher who is a teacher utilizing Online Distance Learning or E-Learning got enthusiastic to focus on the level of manifestation of communicative competence among Grade 11 learners utilizing synchronous and asynchronous e-learning in selected public schools in District of Silang, Division of Cavite. The result of this study will help the researcher and the English teachers in becoming aware of the things that should be considered in creating more effective and efficient teaching in the new normal education utilizing the Online Distance Learning; thus, helping them to achieve one of the language education's goals, which is to produce learners with great command in English language.

\subsection{Theoretical Framework}

In formulation of a theoretical perspective of utilizing Online Distance Learning in developing communicative competence, the researcher associated different philosophies and theories of the following eminent individuals which served as the groundwork of the study. These are Dell Hymes' Theory of Communicative Competence (1966), Transactional Distance Learning (1993) by Michael G. Moore and Constructivist Learning Theory by Jerome Bruner (1973). First, Theory of Communicative Competence by Hymes (1966) revealed the relationship between language and social context. He clarified that it includes not only knowledge of formal grammatical structure but also of form/function relationships learned from all language uses in social life. Second, Moore (1997) defined Transactional distance as distinguished from physical or temporal distance that refers to the psychological or communicative space which separates instructor from learner in the transaction between them, occurring in the structured or planned learning situation. In the study of Huang (2015), she described in Moore's original model that the extent of transaction distance is a function of dialogue, course structure, and leaner autonomy. Conceptually, the relationship of dialogue, structure, and learner autonomy to transactional distance is central to understanding that learning in online distance modality will result to successful outcome when these three impeccably worked in together.

Lastly, the Constructivist Learning Theory by Jerome Bruner (1983) supported how the learners can practice 
A study on teaching strategies and communicative competence in online distance learning among grade 11

and improve their communicative competence through interactive and objective-driven activities in online distance learning. He defined Constructivist Learning Theory as a philosophy which enhances students' logical and conceptual growth. According to Richardson (as cited in Islam 2019), Constructivism is a theory of knowledge and knowing that make learners personal considerations based on their background knowledge, belief, and ideas with which is the result experience. In response to the preferred Online Distance Learning or E-learning of the Department of Education, Constructivist Learning Theory could be a foundation in the planning and implementation of the meaningful and collaborative learning tasks which enhance communicative competence through real-world communicative practices.

\subsection{Research Design}

The study used the explanatory sequential mixed method. The researcher conducted both quantitative and qualitative research. First, the researcher conducted a survey on Master Teachers' and English Teachers' assessment of the level of manifestation of teaching strategies in developing communicative competence of learners using synchronous and asynchronous e-learning. Next, an interview was conducted to obtain the English Teachers' experiences as regards e-learning using synchronous and asynchronous in developing communicative competence of the Grade 11 learners. Data have been collected, analyzed, compared the results and interpreted to find out the over-all assessment of the level of manifestation of teaching strategies in developing communicative competence among Grade 11 learners using synchronous and asynchronous e-learning.

\subsection{Research Paradigm}

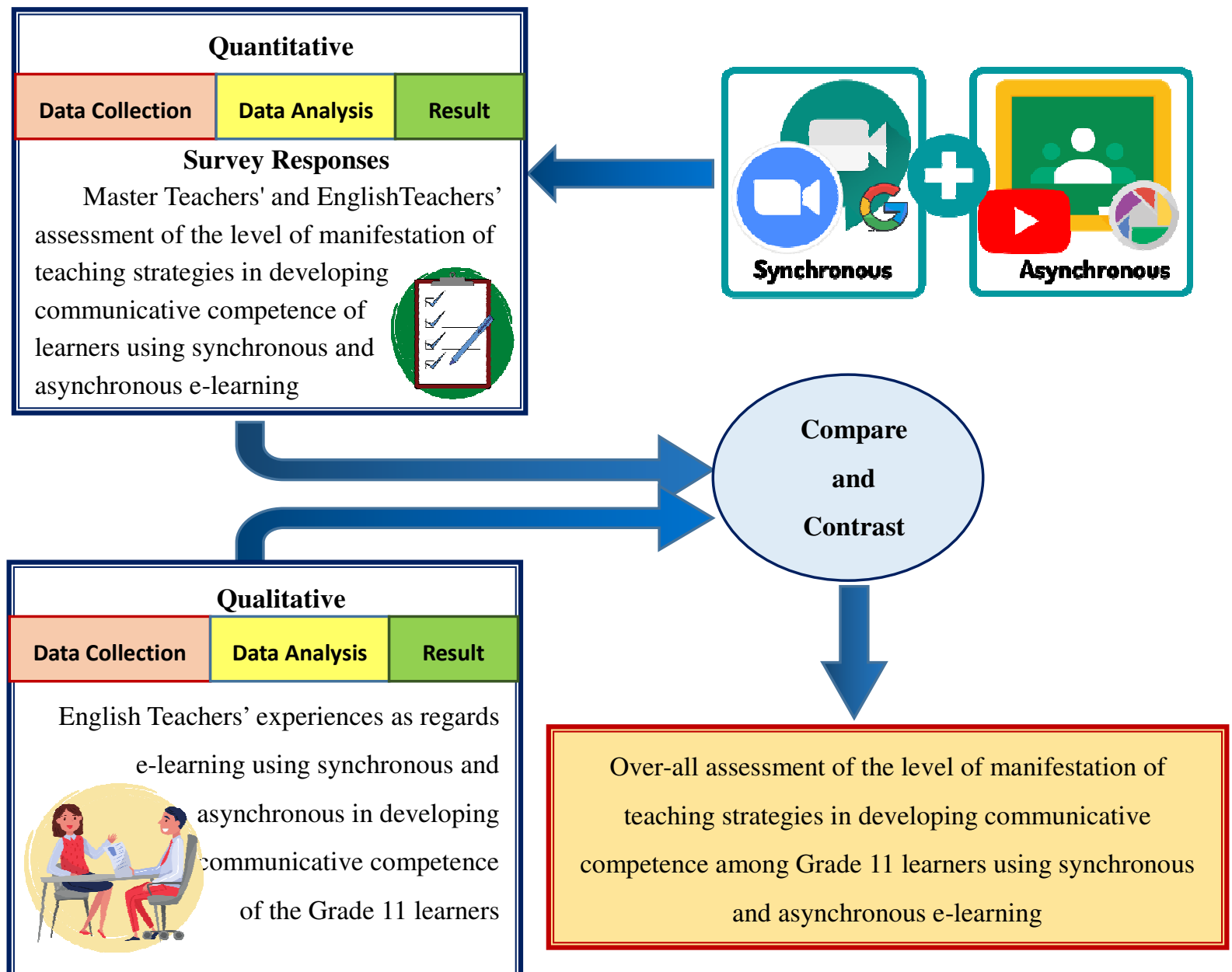

Figure 1. Research Paradigm 
Statement of the Problem - The study aimed to assess the level of manifestation of teaching strategies in developing communicative competence among Grade 11 learners in the District of Silang, Division of Cavite utilizing synchronous and asynchronous e-learning. Specifically, it is premeditated to find out the level of manifestation of teaching strategies of the English teachers in developing the communicative competence of the Grade 11 learners as assessed by Master Teachers and Grade 11 English Teachers in the District of Silang, Division of Cavite in terms of Synchronous E-Learning and Asynchronous E-Learning. Moreover, it was designed to explore if there was a significant difference between the assessments of the Master Teachers and Grade 11 English Teachers as regards the level of manifestation of the teaching strategies in developing communicative competence. Then, to see the level of Grade 11 students' communicative competence in terms of grammatical competence and discourse. Moreover, it sought to investigate if there was any significant relationship between the level of manifestation of teaching strategies and the level of Grade 11 learners' level of communicative competence. In addition, it ought to determine the challenges that the teacher participants encounter in developing communicative competence among Grade 11 learners in both synchronous and asynchronous e-learning. Lastly, based on the findings, it sought to come up with a communicative teaching framework.

Hypotheses - The study assumed that there was no significant difference in the assessments of the Master Teachers and Grade 11 English Teachers as regards the level of manifestation of teaching strategies in developing communicative competence of Grade 11 students utilizing synchronous and asynchronous e-learning. Congruently, it anticipated that there was no significant relationship between the level of manifestation of teaching strategies in developing communicative competence of Grade 11 students utilizing synchronous and asynchronous e-learning and the level of communicative competence of the Grade 11 students.

Scope and Delimitations - The major focus of the study was to assess the level of manifestation of teaching strategies in synchronous and asynchronous e-learning and the level of Grade 11 learners' communicative competence in terms of grammatical and discourse competence. The respondents of the study were Master teachers and Grade11 English teachers in the District of Silang, Division of Cavite. The participants were the Grade 11 English teachers. Data gathering has been conducted between months of April and May of School Year $2020-2021$.

\section{Related Literature and Studies}

The "new normal" education system greatly affects the teaching-learning process especially the asserted need on developing communicative competence. Ahmed (2019) \& Madina, et al. (2020), defined communicative competence as one's ability to communicate appropriately and accordingly with observance of proper grammatical structures. Perveen (2016) elucidated that communicative competence is achieved if the learner can broadly speak the language, participate actively and attained higher order thinking skills. Besides, the manifestation of the e-learning activities in the development of the learner's communicative competence is the major concern of this study. Francescucci (2018), Scheiderer (2020) and Thompson (2019) similarly defined Synchronous Online Learning as real- time online learning where students are required to attend the virtual meetings or learning sessions at specific date and time. In addition, Watts (2016), Bhandari (2021) and Pwarno (2018) explicated that interactive and collaborative activities are realizable in synchronous e-learning wherein real-time language simulation strengthens learner's grammatical and sociolinguistic aspects. Contrary, Perveen (2016), Joksimović et al. (2015) and Bettinger et al. (2016) noticed that low learner's participation is conspicuous in synchronous e-learning. Hence, the utilization of asynchronous e-learning is at demand. These views embolden the researcher to see the possibilities of incorporating the utilization of asynchronous e-learning in developing learner's communicative competence.

Angethomas (2019), Perveen (2016), and Thompson (2019) described asynchronous learning as teacher and student interactions that provides opportunity for the learners to study at their own pace and time. She added that delayed response in asynchronous e-learning may develop learner's higher order thinking skills. Jacobi (2017)

88 Consortia Academia Publishing (A partner of Network of Professional Researchers and Educators) 
and Francescucci (2018) contradicted its gain as they deduced that asynchronous e-learning do not provide opportunity to speak. Pong (2016) supported this as she claimed that the absence of real- time feedback and interaction in asynchronous e-learning is apparent. Their conclusions about the advantages and disadvantages of online distance learning support the findings of the study. Hrastinski (2015) and Lin et al. (2019) had agreed upon the notion that combination of synchronous and asynchronous e-learning could be beneficial in the successful learning. They concluded that pre-recorded video lessons, reflections and other readily materials can help the learners to have the profound understanding of the concepts while synchronous e-learning provides them the opportunity to practice and acquired the communicative competence.

In support to this, Huang and Perveen (2017) emphasized that the design and implementation of any e-language learning pedagogy should provide maximum support to students through clear and accurate instructions and resources in achieving objectives to avoid frustration especially in providing a real time interaction, immediate feedback and a feel of human touch. Furthermore, Pong (2016) and Valentine (as cited in Rapanta, 2017) heightened that in order to effectively utilize the synchronous and asynchronous e-learning, teachers as well as the learners should be digitally competent. These conceptions support the researcher's belief that appropriate utilization of synchronous and synchronous e-learning could help the learners to acquire the communicative competence.

\section{Methodology}

The study was quantitative in nature, yet employing mixed - methods research. The researcher used the explanatory sequential design to answer the research questions. According to Edmonds and Kennedy (2017), the explanatory-sequential approach is a sequential approach used when the researcher is interested in following up the quantitative results with qualitative data. Thus, the qualitative data were used in the subsequent interpretation and clarification of the results from the quantitative data analysis. A researcher- made questionnaire was used to answer the formulated research questions. Respondents' responses to the self-made questionnaire revealed the level of manifestation of teaching strategies in developing the Grade 11 students' communicative competence as synchronous and asynchronous e-learning are implemented. The survey questionnaire was pilot tested to ten Grade 11 English Teachers. Cronbach's Alpha was used in processing the result of the pilot testing of the survey. Afterwards, result ran thru SPSS. To measure the communicative competence of the Grade 11 learners, the researcher constructed a pen and paper test derived from the MSA Reviewer concentrated on grammatical and discourse competence. This was pilot tested to ten (10) Grade 11 learners. As for the result, all the questions were acceptable. Open-ended questions were used during the conduct of interview. These research instruments were validated by the adviser and three (3) graduate school professors.

The extant study was conducted in selected public senior high schools utilizing Online Distance Learning in the District of Silang, Division of Cavite. For quantitative part, the respondents of the study had been chosen through Simple Random Sampling that compromised the involvement of seven (7) Master teachers, twentythree (23) Grade 11 English teachers and four hundred fifty (450) Grade 11 learners. Meanwhile, for the qualitative part, the researcher utilized the purposeful sampling wherein seven (7) participants were selected. Before the actual data gathering, the researcher prepared letters requesting for the consent of the Schools Division Superintendent, Public School District Supervisor and School Heads. Letters for the cooperation and permission of the respondents had also been prepared.

After securing approval, the researcher distributed the survey questionnaires to the Master teachers and the Grade 11 English teachers at District of Silang, Division of Cavite in a google form. The collected data were subjected to statistical treatment-correlation and multiple linear regression with the help of the school official statistician. Various statistical treatments were applied in the study by the statistician using Statistical Package for Social Sciences (SPSS). First, the mean and the four-point Likert Scale were used to describe the level of manifestation of teaching strategies of the English teachers in developing the communicative competence of the Grade 11 learners as assessed by Master Teachers and Grade 11 English Teachers in the District of Silang, 
Calma, R.

Division of Cavite. Next, the t-test was used to analyze significant difference between the assessments of the Master Teachers and Grade 11 English teachers as regards the level of manifestation of the teaching strategies in developing communicative competence. Ultimately, the Chi-squared Test was used to establish the relationship between the level of manifestation of teaching strategies and the Grade 11 learners' level communicative competence.

For qualitative aspect of data gathering, the researcher interviewed the respondents via google meet. The process started by explaining to the participants its purpose, pointing out that the interview would be recorded, indicating that the identity of the respondents would be confidential, and mentioning that the interview would be recorded and transcribed for analysis purposes. Next, a consent form was read and signed by the participants before the actual interview. The sessions were recorded and transcribed. With this, the school official analyst was approached to guide the researcher as regards qualitative analysis. Using interpretative phenomenological analysis, the data were synthesized and interpreted to draw insights, reflections, and recommendations.

\section{Results and Discussions}

Based on the data gathered and after cautious and comprehensive analysis of the investigation, the following are the findings of the study in summarized form. The findings below showed the level of manifestation of teaching strategies of the English teachers in developing the communicative competence of the Grade 11 learners as assessed by Master Teachers and Grade 11 English Teachers in the District of Silang, Division of Cavite in terms of Synchronous E-Learning.

Table 1

Manifestation of Teaching Strategies in Developing the Communicative Competence in Synchronous Learning

\begin{tabular}{|c|c|c|c|c|c|c|}
\hline \multirow{2}{*}{ Indicators } & \multicolumn{2}{|c|}{ Master Teacher } & \multicolumn{2}{|c|}{ Teacher } & \multicolumn{2}{|c|}{ Composite } \\
\hline & M & VI & M & VI & M & VI \\
\hline $\begin{array}{l}\text { 1. Provides opportunities for the students to speak and } \\
\text { communicatively use English during the online class discussion. }\end{array}$ & 3.86 & FM & 3.83 & FM & 3.85 & FM \\
\hline $\begin{array}{l}\text { 2. Holds interactive and collaborative activities to maximize } \\
\text { communication among the students. }\end{array}$ & 3.86 & FM & 3.65 & FM & 3.76 & FM \\
\hline $\begin{array}{l}\text { 3. Provides opportunity for the students to develop fluency while } \\
\text { communicating with the teacher and with their classmates. }\end{array}$ & 3.57 & FM & 3.52 & FM & 3.55 & FM \\
\hline $\begin{array}{l}\text { 4. Encourages the students to report or present in class assigned } \\
\text { topic for them to enhance their communication skills. }\end{array}$ & 3.71 & FM & 3.61 & FM & 3.66 & FM \\
\hline $\begin{array}{l}\text { 5. Carefully constructs High Order Thinking Skills type of } \\
\text { questions that will be raised during the online session for the } \\
\text { student to be more critical in communicating themselves while } \\
\text { answering. }\end{array}$ & 4.00 & FM & 3.70 & FM & 3.85 & FM \\
\hline $\begin{array}{l}\text { 6. Makes use of rubrics in assessing the communicative } \\
\text { competence of the students during the interactive discussion of the } \\
\text { lesson/topic. }\end{array}$ & 4.00 & FM & 4.00 & FM & 4.00 & FM \\
\hline $\begin{array}{l}\text { 7. Links the different skills such as speaking, reading and listening } \\
\text { during the online session since they usually occur in the real world } \\
\text { where the students are expected to communicate. }\end{array}$ & 3.71 & FM & 3.65 & FM & 3.68 & FM \\
\hline $\begin{array}{l}\text { 8. Provides communicative activities that encourage and require the } \\
\text { students to speak with and listen to their classmates and to the } \\
\text { teacher. }\end{array}$ & 3.71 & $\mathrm{FM}$ & 3.13 & FM & 3.42 & FM \\
\hline $\begin{array}{l}\text { 9. Tries that in testing productive skills, emphasis is placed on } \\
\text { appropriateness rather than on ability to form grammatically } \\
\text { correct sentences. }\end{array}$ & 3.57 & FM & 3.39 & FM & 3.48 & FM \\
\hline $\begin{array}{l}\text { 10. Focuses to the use of the English in functional aspects of } \\
\text { language. }\end{array}$ & 4.00 & FM & 3.70 & FM & 3.85 & FM \\
\hline General Assessment & 3.80 & FM & 3.62 & FM & 3.71 & FM \\
\hline
\end{tabular}

Legend: 3.26-4.00 Fully Manifested (FM) 2.51-3.25 Manifested (M) 1.76-2.50 Slightly Manifested (SM) 1.00-1.75 Not Manifested (NM)

As gleaned in the Table 1, the general assessment was $\mathbf{3 . 7 1}$ and interpreted as Fully Manifested. The English teacher makes use of rubrics in assessing the communicative competence of the students during the interactive discussion of the lesson/topic had the highest mean which was $\mathbf{4 . 0 0}$ and interpreted as Fully

90 Consortia Academia Publishing (A partner of Network of Professional Researchers and Educators) 
Manifested. This implies that utilization of rubrics is an effective assessment tool to assess the learner's e-learning performance which will harness learner's awareness with regard to their communicative progress. In utilizing appropriate rubrics, the students can be guided on how they will execute their written and oral performance in order to develop their communicative competence. When the learners are guided as to how they will be assessed, they will perform accordingly unconsciously realizing that the communicative competence is being acquired. Also, the use of rubrics enables the English teachers to gather concrete data reflecting the progress of the learners in mastering the intended communicative competence. Thus, they will able to strengthen the learner's language imperfections to produce communicative competent speakers. A well- designed Rubrics with appropriate, concrete and precise indicators is an effective tool to assess the learners' progress towards developing communicative competence in online distance learning. Rubrics can be tailored to specific lesson objectives depending on the nature of execution. Thus, school administrators should consider careful planning and crafting of each of the rating scale and descriptions as a requisite for every task-based performance implemented by teachers within the e-learning classroom.

Magger (as mentioned in Saeed, Ismail, and Eng, 2019) emphasized that evaluators must always understand the conditions and terms for each competency on a rubric to produce unbiased feedback to learner's communicative progress to empower them to speak without comprehension difficulties for the listener and to maintain the communicative ideas more effectively. Meanwhile, The English teacher provides communicative activities that encourage and require the students to speak with and listen to their classmates and to the teacher had the least mean which was $\mathbf{3 . 4 2}$ and interpreted as Fully Manifested implies that the teachers also need to provide communicative activities that will enable learners to learn various language conventions such as language formation, syntax, pragmatics, vocabularies, and other language aspects which can help them to gain language fluency. If the learners are exposed to a communicative environment, adaptation of the target language could be manifested naturally. School administrators should include those considerations in crafting the "new normal" curriculum for effective e-language learning.

Validating the survey findings, the following themes emerged from the solicited participants' responses on experiences in e-learning using synchronous in developing communicative competence among Grade 11 learners. From these, Theme 1: Real-Time Communicative E-Learning Activities was derived which annotates the participants' experiences on how real-time communicative activities develop the learners' communicative competence. It elucidated that learner's exposure to actual language environment will help them acquire language fluency. Particularly, this theme had subordinate themes which were: a) Interactive and Collaborative Activities as Product and Performance Task; b) Real-life Situation Activities as Language Simulation; and c) 21st Century Skills as Communicative Competence' Scaffold.

Implicitly, the demand for learner-centered classrooms is highly encouraged in the new normal especially in synchronous e-learning. Interactive activities provide numerous benefits for a learner's physical well-being, learning, mental, social and behavioral aspects. It also provides opportunity for the learners to receive comprehensible and substantial inputs about correct and appropriate language distinct as well as constructive feedback as regards to their communicative competence development. By integrating interactive and collaborative activities, learners are more exposed to actual language environment which will help the acquisition of communicative competence attainable.

English teacher serves as the designer and implementer in the synchronous e-learning. Realistically, it is the teacher's duty to create a meaningful and functional communicative environment to encourage the learners to participate in the command of English language. However, planning the delivery of instruction should not be limited on the behavioral and cognitive language acquisition, s/he should also incorporate socio-cultural and contextual perspectives. Sociocultural theory is an emerging theory in psychology that looks at the important contributions that society makes to individual development. It denotes integrating situated-social practice. The task of the school administrators is to ensure that the materials used by the teachers for interactive and collaborative works are well-reviewed and validated. 
Calma, R.

Pardede (2020) claimed that the 4Cs are acknowledged as a part of the main skills of the 21st century which includes the 4Cs (communication, collaboration, critical thinking, and creativity). Languages are basically a means of communication. Thus, by learning English, students are facilitated to acquire and develop communication skills, and by putting the integrated skills learning in a blended learning environment, students will also develop digital communication skills.

Congruently, Theme 2: Rubrics as Effective Communicative Assessment Tool annotated the role of rubrics in assessing the learner's communicative competence in asynchronous e-learning. It emerged from the respondents' answers explicated that rubrics provide objective and effective assessment to guide the learners towards the target outcome. Linguistically, use of rubric is important in assessing the learner's progress and detecting decelerating communicative skills. In the new normal language learning, crafting its content and descriptions needs careful and analytical planning to come up with an effective tool that will assess the Most Essential Learning Competencies (MELCs) and elevating the learner's communicative competence. Saeed, Ismail, and Eng (2019) underscored that prioritizing the effective design, understanding, and competent use of rubrics is paramount due to the rise of non-traditional performance-based assessment such as interactive and collaborative e-language activities.

Table 2 showed the level of manifestation of teaching strategies of the English teachers in developing the communicative competence of the grade 11 learners as assessed by master teachers and grade 11 English teachers in terms of Asynchronous E-Learning.

Table 2

Manifestation of Teaching Strategies in Developing the Communicative Competence in Asynchronous Learning

\begin{tabular}{|c|c|c|c|c|c|c|}
\hline \multirow{2}{*}{ Indicators } & \multicolumn{2}{|c|}{ Master Teacher } & \multicolumn{2}{|c|}{ Teacher } & \multicolumn{2}{|c|}{ Composite } \\
\hline & M & VI & M & VI & M & VI \\
\hline $\begin{array}{l}\text { 1. Formulates learning objectives as regards the students' } \\
\text { accomplishment of tasks and activities based on the discussed } \\
\text { topic/ lesson during the online session. }\end{array}$ & 4.00 & FM & 3.83 & FM & 3.92 & FM \\
\hline $\begin{array}{l}\text { 2. Uses communicative tests that are meant to mirror actual } \\
\text { communication, assessing the students' ability to use the various } \\
\text { skills in an integrated way, by doing tasks similar to those they } \\
\text { need/will need to perform in real-life situations beyond the } \\
\text { classroom. }\end{array}$ & 4.00 & FM & 3.43 & FM & 3.72 & FM \\
\hline $\begin{array}{l}\text { 3. Utilizes data-based lesson materials to serve as baseline for the } \\
\text { students to express themselves both in speaking and writing as } \\
\text { forms of communication. }\end{array}$ & 3.14 & M & 2.74 & M & 2.94 & M \\
\hline $\begin{array}{l}\text { 4. Provides opportunities for the students to write communicatively } \\
\text { using English as they perform activities and exercises relative to } \\
\text { the topic/lesson learned during the online discussion. }\end{array}$ & 3.86 & FM & 3.57 & FM & 3.72 & $\mathrm{FM}$ \\
\hline $\begin{array}{l}\text { 5. Provides the students to individually learn through self-paced } \\
\text { method guided by clear and accurate instructions/directions. }\end{array}$ & 4.00 & FM & 3.83 & FM & 3.92 & FM \\
\hline $\begin{array}{l}\text { 6. Provides opportunity for the students to develop writing skills as } \\
\text { they are instructed to come up with the varied writing categories } \\
\text { such as essay, reflection and reaction paper. }\end{array}$ & 3.43 & FM & 3.43 & FM & 3.43 & FM \\
\hline $\begin{array}{l}\text { 7. Encourages the students to do different types of writing and } \\
\text { speaking performances to enhance their communication skills. }\end{array}$ & 3.71 & FM & 3.61 & FM & 3.66 & FM \\
\hline $\begin{array}{l}\text { 8. Provides the students the chance to apply grammatical } \\
\text { knowledge, syntax and morphology in their accomplishing tasks. }\end{array}$ & 3.86 & FM & 3.57 & FM & 3.72 & FM \\
\hline $\begin{array}{l}\text { 9. Allows the learners to use their higher order learning skills as } \\
\text { they can keep thinking about a problem for an extended time } \\
\text { period and may develop divergent thinking. }\end{array}$ & 3.71 & FM & 3.26 & FM & 3.49 & FM \\
\hline $\begin{array}{l}\text { 10. Believes that that not only should the test content be totally } \\
\text { relevant for a particular group of students but the tasks set should } \\
\text { relate to real-life situations, usually specific to a particular place or } \\
\text { culture. }\end{array}$ & 3.71 & FM & 3.57 & FM & 3.64 & FM \\
\hline General Assessment & 3.74 & FM & 3.48 & FM & 3.61 & FM \\
\hline
\end{tabular}

Legend: 3.26-4.00 Fully Manifested (FM) 2.51-3.25 Manifested (M) 1.76-2.50 Slightly Manifested (SM) 1.00-1.7 Not Manifested (NM)

Based from Table 2, the general assessment was 3.61 and interpreted as Fully Manifested. The English 
A study on teaching strategies and communicative competence in online distance learning among grade 11

teacher formulates learning objectives as regards the students' accomplishment of tasks and activities based on the discussed topic/ lesson during the online session and provides the students to individually learn through self-paced method guided by clear and accurate instructions/directions had the highest mean which was $\mathbf{3 . 9 2}$ and interpreted as Fully Manifested. It implies that provision of accurate and clear instructions/ directions helps the learners to individually learn through self-paced method. English teachers carefully articulate learning objectives to ensure its alignment with the Most Essential Learning Competencies as mandated by the Department of Education. Additionally, they incorporate learning objectives that will comprise activities which will help develop the learners' communicative competence. With the communicative competence elevating objectives, in alignment with MELCs, systematize learning instruction will be effectively implemented which might result to mastery of the expected competencies. It will also meritoriously address the varying needs of learners and the challenges of instructional deliveries. Furthermore, it will also provide an opportunity to determine the proper road map of progression within a subject and how it relates with prior and future learning opportunities.

In accordance with Department of Education Order No. 12, series of 2020 entitled 'Adoption of Basic Education Learning Continuity Plan for School Year 2020-2021 in Light of the COVID-19 Public Health Emergency', they release the Most Essential Learning Competencies to be used nationwide by the field implementers. The teachers are required to follow the MELCs in crafting their learning objects, instructions and assessments. With this, school administrators ensures that the new normal education focus on the most essential and indispensable competencies that our learners must acquire, as we anticipate challenges in the implementation new learning modalities. Moreover, Zhou (2017) stated that articulating learning objectives helps instructors select and organize course content, and determine the types of assessments and activities to build for a course. Also, it aids them to identify the kinds of materials and topics to produce concrete evidences of how learners applied the communicative competencies.

Meanwhile, The English teacher utilizes data-based lesson materials to serve as baseline for the students to express themselves both in speaking and writing as forms of communication had the least mean which was $\mathbf{2 . 9 4}$ and interpreted as Manifested implies that teachers encounter difficulty in utilizing data-based materials because of lacks of digital literacy. Thus, teachers and students may consider data-based lesson or material to be barriers particularly prevalent among teachers with more low-income students. The intervention of school administrators to provide upskilling webinars and trainings on utilization of affordable or totally free data-based materials should be observed and implemented accordingly to promote digital literacy among teachers and learners. Deduction of this problem could be a big help to have a smooth language e-learning.

According to Valentine (as cited in Rapanta, 2017), equipment and hardware malfunctions can be a great detriment to the effectiveness of distance learning. When a problem occurs in a class everything comes to a standstill and the learning environment is interrupted. The qualitative part of the study resulted to the following themes which illustrated the solicited responses of the participants as regards to their experiences in developing Grade 11 learners' communicative competence in asynchronous e-learning. The responses of the participants aided the researcher to glean the comparison between the survey result and the interview responses. From their answers, two themes were derived: Theme 1: Self-paced Method as Communicative Assessment Tool; and Theme 2: Learner's Capability as Center of E-Learning Endeavors.

Explicitly, Theme 1: Self-paced Method as Communicative Assessment Tool derived from the participants solicited responses noted that they utilized self-paced method in their asynchronous e-learning in developing the learner's communicative competence. In particular, they assigned learners to come up with offline oral and written outputs. Notably, their purpose of providing offline oral outputs is to develop the learner's speaking communicative skills while assigning written outputs is to enhance their language convention and how well they do in written text. In behavioral perspective, the teaching of communicative competence was intertwined with the concept of Metacognition. Ayyanathan (as cited in Haukås, Bjørke, and Dypedahl, 2018) referred it to higher order thinking, which involves active control over the cognitive processes engaged in learning. It denotes that teachers should engage students in reflection or otherwise promoting self-awareness of 
Calma, R.

their learning process. It also enables the learners to be successful and has always been associated with intelligence. Activities that involve planning, monitoring, comprehension, evaluating the progress towards the completion of a task is metacognitive in nature. The learners perform well when they are taught to apply their cognitive resources through metacognitive control. It would also enable the learners to acquire communicative competence on their own in pertinent situation.

Subsequently, Theme 2: Learner's Capability as Center of E-Learning Endeavors illuminated the participants shared experiences on taking into consideration the learner's capabilities in designing the asynchronous e-learning activities. Meeting their needs and capabilities onset will help the teacher to carefully design e-language classroom which entails critical and extensive acquisition of communicative competence concentrating on grammatical and discourse competence. Hence, determining learner's needs and capabilities will help the school administrators to come up with a program heightening quality language learning. If the learners are capable of doing the prepared e-classroom activities, learning with enjoyment could be plausible leading to authentic language acquisition. Moore and Hodges (2020) capitalized on their blog that students need should be primary consideration in designing e-learning activities due to various internal and external factors affecting the learner's e-learning performance.

The overall essence of the participants' testimonies and sharing of their experience with the utilization of synchronous and asynchronous e-learning influence the development of learner's communicative competence. The participants postulated that providing interactive and collaborative activities during synchronous e-learning and exposing the learners to real-life situations enable the learners to practice the English language and elevate their sociolinguistic, discourse and strategic competence. Meanwhile, designing contextualized content and activities incorporating grammar construction, syntax formation, and discourse analysis and application in asynchronous e-learning promote grammatical and discourse competence. Thus, the combination of both synchronous and asynchronous e-learning environment gear toward developing communicative competence.

Apparently, Table 3 showed the test of Significant Difference on the assessments of the Master Teachers and Grade 11 English teachers as regards the level of manifestation of the teaching strategies in developing communicative competence.

Table 3

Test of Significant Difference on the Assessments of the Master Teachers and Grade 11 English teachers

\begin{tabular}{lllll}
\hline Variables & T test & P value & Remarks & Decision \\
\hline Synchronous & 2.859 & .008 & Significant & Reject Ho \\
Asynchronous & 3.589 & .001 & Significant & Reject Ho \\
\hline
\end{tabular}

Based from Table 3, the probability values were all less than the level of significance at .05 thus rejected the null hypothesis. It can be stated that there was Significant Difference on the assessments of the Master Teachers and Grade 11 English teachers as regards the level of manifestation of the teaching strategies in developing communicative competence. This implies that although the combination of synchronous e-learning activities and asynchronous e-learning activities influence the learner's communicative competence in online distance learning, the two groups of respondents do not have the same assessment as regards the level of manifestation of the teaching strategies in developing communicative competence which might be due to their nature of work and position. The researcher only hopes that both groups of respondents agree that providing opportunities to learners to practice English language during interactive and collaborative activities in synchronous e-learning, and supplementing well-crafted self-paced communicative activities in asynchronous e-learning help in elevating learner's communicative competence. Henceforth, this will help the school administrators to design an e-language curriculum incorporating synchronous and asynchronous e-learning activities heightening communicative competence.

Perveen (2016) claimed that synchronous activities should be scaffolded over asynchronous activities to

94 Consortia Academia Publishing (A partner of Network of Professional Researchers and Educators) 
A study on teaching strategies and communicative competence in online distance learning among grade 11 help the learners develop the communicative competence.

To continue, Table 4 showed the level of Grade 11 learners' communicative competence in terms of grammatical competence.

\section{Table 4}

Level of Grade 11 Learners' Communicative Competence in terms of Grammatical Competence

\begin{tabular}{lll}
\hline Indicators & $\mathrm{F}$ & $\%$ \\
\hline Outstanding & 137 & 30.44 \\
Very Satisfactory & 74 & 16.44 \\
Satisfactory & 133 & 29.56 \\
Fairly Satisfactory & 35 & 7.78 \\
Did not Meet Expectation & 71 & 15.78 \\
\hline Total & 450 & 100.00 \\
\hline
\end{tabular}

Legend : 90-100 Outstanding; 85-89 Very Satisfactory; 80-84 Satisfactory; 75-79 Fairly Satisfactory; 74 below Did not meet expectations

It was reflected on Table 4 that $\mathbf{3 7 9}$ learners or $\mathbf{8 4 . 2 2 \%}$ of the learners who took the examination had developed their communicative competence in terms of grammatical competence. It implies that teachers and school administrators should design a curriculum which provide opportunities for further language expansion, specifically for enhancing learner's grammatical competence are manifested on the e-learning activities which heightened correct grammar construction, proper and precise syntax formation and contextualized discourse-related activities. If the learners are well-conversed with proper grammatical structures, procurement of grammatical competence could be evident.

According to Saarista (2020), Grammar learning includes not only the rules for correct writing, spelling and speaking but also how language should be written/spoken in a correct and appropriate way such the correct way of writing or taking grammatical correctness or proper sentence construction. Meanwhile, 71 learners or 15.78\% did not meet the expectation. This implies deterioration of learner's grammatical competence is may be due to lack of vocabulary, morphological problems, and weak grammatical foundation. Hence, there is a need for the positive measures to support the students regarding the determined problem. In a study conducted by Xiao (2019), he noticed that most students feel that grammar learning is rather boring, so appropriate strategies and methods for grammar learning are extremely important. On the other hand, Table 5 showed the level of Grade 11 learners' communicative competence in terms of discourse.

\section{Table 5}

Level of Grade 11 Learners' Communicative Competence in terms of Discourse

\begin{tabular}{lll}
\hline Indicators & $\mathrm{F}$ & $\%$ \\
\hline Outstanding & 7 & 1.56 \\
Very Satisfactory & 13 & 2.89 \\
Satisfactory & 103 & 22.89 \\
Fairly Satisfactory & 91 & 20.22 \\
Did not Meet Expectation & 236 & 52.44 \\
\hline Total & 450 & 100.00 \\
\hline
\end{tabular}

Legend : 90-100 Outstanding; 85-89 Very Satisfactory; 80-84 Satisfactory; 75-79 Fairly Satisfactory; 74 below Did not meet expectations

Table 5 revealed that 214 learners or $\mathbf{4 7 . 5 6 \%}$ of the learners who took the examination had developed their communicative competence in terms of discourse. This implies that the design and contextualized content of the e-learning task-based activities influence the development of learner's discourse competence. Martin (2015) claimed that Discourse competence, as a component element of communicative competence, is a crucial element of the competences required by students when engaged in academic reading and writing. Meanwhile 236 learners or $\mathbf{5 2 . 4 4 \%}$ did not meet the expectation. The percentage is even bigger that those who had developed 
Calma, R.

their discourse competence. This implies that there are e-learning activities which do not intensify discourse development. E-language teachers may have been unable to incorporate discourse-structuring undertakings focusing on proper use of lexical cohesion, analysis and comprehension. Also, decelerated discourse development could be attributed to lack of vocabulary and inappropriateness of the e-language content to learner's background. Hence, appropriate e-learning actions should be done in order to enhance this aspect of learner's communicative competence.

Correspondingly, Xiao (2019) conducted a study resulted to low discourse competence of senior high school learners. The result was influenced by their low English language exposure and less focus of this dimension in the teaching of English. Thus, more exposure to English language environment is recommended. Conspicuously, Table 6 showed the test of significant relationship between the level of manifestation of teaching strategies and the level of Grade 11 learners' level of communicative competence.

\section{Table 6}

Test of Significant Relationship between the Manifestation of Teaching Strategies and Learners' Communicative Competence

\begin{tabular}{llllll}
\hline Variables & & Chi Square & P value & Remarks & Decision \\
\hline Synchronous & Grammatical Competence & 4.53 & .716 & Not Significant & Accept Ho \\
& Discourse & 13.768 & .131 & Not Significant Accept Ho \\
Asynchronous & Grammatical Competence & $12.778^{\mathrm{a}}$ & .173 & Not Significant & Accept Ho \\
& Discourse & 8.100 & .324 & Not Significant & Accept Ho \\
\hline
\end{tabular}

As reflected from Table 6, there was no significant relationship between the level of manifestation of teaching strategies and the level of Grade 11 learners' level of communicative competence. As shown in their probability values of $.716, .131, .173$ and .324 respectively, they were all greater than the level of significance at .05. Thus, it accepted the null; it can be stated that there was no significant relationship on the level of manifestation of teaching strategies and the level of Grade 11 learners' level of communicative competence. The finding stating that there was no significant relationship on the level of manifestation of teaching strategies and the level of Grade 11 learners' level of communicative competence implies that there are other factors that might have been affecting the students' level of communicative competence. It may be attributed to behavioral and technical predicaments in online distance learning that defer learner's language acquisition. Behavioral problems include their lack of motivation and learner's superficial perspective of language learning.

Meanwhile, technical problems comprise instability of internet connection and difficulty in accessing the materials and e-learning activities which can be associated to lack of digital literacy. The aforementioned problems affect the delivery of language instruction, assessment and learner's performance in online distance learning which indirectly impact the development of learner's communicative competence. Therefore, e-language teachers should take into considerations the learner's interests, needs, abilities, personal and technical capabilities in designing the e-language learning activities to attain communicative competence among learners. These concerns should be also address to higher authority for the planning phase of curriculum construction specifically in distance education. Stickler (2015) argued that online language teaching is a socio-constructivist endeavor, teachers should be acquiring new skills to use pedagogically transformative practice with the potential to empower both online teachers and online students.

The following solicited responses from the participants revealed the challenges they met in utilizing synchronous e-learning, specifically in developing the learner's communicative competence. These included low level of learners' participation and poor learners' attendance. Notably, Participants 1, 6 and 7 are in troubled about the low level of their learners' participation. In particular, Participant 1 described her learners as inactive. Then, Participant 6 said that most of her students don't have initiative when it comes to participation. Last, Participant 7 elaborated that this problem is merely due to lack of confidence in communication.

Inauspiciously, the participants clearly denoted that low level of participation is existing in synchronous e-learning environment, that's why teachers should address this problem accordingly. They should understand 
A study on teaching strategies and communicative competence in online distance learning among grade 11

some reasons beyond the learners' low level of participation. Congruently, this may be due to various factors which may include the inappropriate e-learning activities, their unconducive learning environment, inaccessibility, insufficient technological skills, or even lack of motivation. Those considerations should be taken into account by the English teachers as curriculum designer and implementer.

According to Joksimović et al. (2015), low learner participation is one of the most significant issues in online education. This could be caused by poorly designed interaction opportunities for learners. Hence, teachers should provide them a well-designed interactive activity will not just improve their self-esteem but also their communicative fluency. Moreover, Participant 3 mentioned that poor learner's attendance is one of their concern in synchronous e-learning. Contemplating on her shared experience, it was reflected that learner's attendance is also a challenge to online teachers; and based from the participant's experience, the teacher can't force the learners to attend the online class as pertinent in DepEd Order 12, s.2020. If not physically present, teachers will have no means of assessing their communicative competence. The preparation and the technology-driven classroom designed for enhancing the expected competencies will not be feasible. To circumvent the latter effects, the teachers should employ various interventions to promote learner's attendance during synchronous e-learning.

Castelo (2020) mentioned that low attendance rates in e-learning are especially apparent in schools with low-income students whose access to devices or an internet connection are limited to none, making it harder for educators to stay in touch with them. On the other hand, the problems encountered in Asynchronous e-learning with regard to developing communicative competence included: lack of digital literacy; late submission of output; plagiarism; provision of immediate feedback; and grammatical and syntactical problem. Evidently, Participant 1 found that learner's lack of digital literacy as a challenge in asynchronous e-learning. Both teachers and learners are digitally challenged when it comes to manipulating the technology-based instruction and learning activities. There are online platforms which are new to teachers as well as to learners that could be a barrier to the educative process. But detecting this problem will bring profound possibilities. Thus, teachers as well as learners are invigorated to be digitally competent. Pong (2016) heightened in her blog that teachers as well as the learners should have the digital competence to achieve quality learning.

Subsequently, Participant 1, 3 and 5 stated that late submission of outputs in asynchronous e-learning was one of their concerns which might be influenced by divergent factors. One of identified cause is procrastination. The absence of the teacher during independent learning gives the feeling of isolation to the learners. Being isolated resulted to demotivation. Designing offline interactive activities which increases learner's motivation is recommended. Fritsche (as cited in Kapifour and Jafari, 2021) pointed out that when student procrastinate, they tend to transfer the language components from their first language to the target language leading to higher grammatical and discourse errors. As manifested on the responses of Participant 3 and 5, submission of plagiarized outputs was an issue when it comes to asynchronous e-learning.

In an asynchronous e-language environment, plagiarism is also prevailing. Asynchronous e-learners tend to submit unoriginal works without recognizing the original author. Hence, e-language teacher finds it difficult to assess the learner's progress with regard to communicative competence. In Metacognitive perspective, the act of committing plagiarism could be reduced through inculcating deeper sense of language learning and functional application of communicative competence in their personal and professional pursuits. Thus, developing communicative competence in asynchronous e-learning can be curated beyond e-language classroom operation. Dendir and Maxwell (2020) found out in their study that cheating has been rampant in the absence of proctoring. Consequently, Perkins, Grezgon \& Roe (2020) determined that low level of communicative competence has something to do with plagiarism.

Based from the responses of Participant 4 and Participant 5, it was reflected that provision of immediate feedback is also a challenge in asynchronous e-learning. Commonly, due to various behavioral and technical predicaments, learners don't submit their outputs on time resulting to delay in the provision of immediate 
Calma, R.

feedback. Hence, developing communicative competence among learners is affected. Likewise, improving learner's grammar errors, syntactical problems, language use, spelling and other related aspects defer. That's why the demand for synchronous intervention arise, because it will enable e-language teachers to provide immediate and constructive feedback with regard to learner's performance. Song, Rice, and Oh (2019) stated that in a typical online course, it is difficult for an instructor to promote positive experiences of interaction for learners because these require immediate and quality feedback from the instructor.

Notably, Participant 2 revealed that grammar difficulty like subject verb agreement, syntax and poor reading comprehension were observed in asynchronous e-learning. It entails that developing learner's communicative competence, specifically, grammatical competence is not fully attained. Besides, some of the common grammatical errors identified in asynchronous e-learning includes errors in subject-verb-agreement, verb tense, noun, preposition, adjective, article, pronoun, adverbs and conjunctions. Another obvious problem congruent to grammatical error is the inconsistent tenses of verb. This problem is attributed to inability of the learner to identify which voice (active or passive) is applicable to the assigned stimuli. These problems resulted from weak foundation of basic grammar rules affect the learner's acquisition of communicative competence.

Subsequently, grammatical errors is connected to syntax. In linguistics, syntax refer on how the words are arranged in sentences. Learner's problem regarding syntax is detectable in the learner's run-on sentences due to improper punctuation, improper use of prepositions and conjunctions and used of apostrophe in word contraction. These are indication of syntactic problem. To address syntactic problem in asynchronous e-learning, teachers are tasked to design activities infringe on syntactic performance to enable learners to adopt accurate standard of syntax formation. According to Singh, Razale \& Ravinthar (2017), the most common grammatical errors in distant learning includes subject-verb agreement, verb tense, noun, preposition, adjective, article, pronoun, adverbs and conjunctions. The analysis of students' grammatical error revealed that the students have poor command of English language. In relation with this, Richards (as cited in Singh, Razale \& Ravinthar, 2017) unveil that overgeneralizations and ignorance of rule restrictions are the main causes of the problem.

Based on the findings of the study, the researcher formulated a framework entitled Online Distance Learning (ODL) Language Teaching Framework to guide the English teachers in designing and crafting their e-learning activities in developing learner's communicative competence.

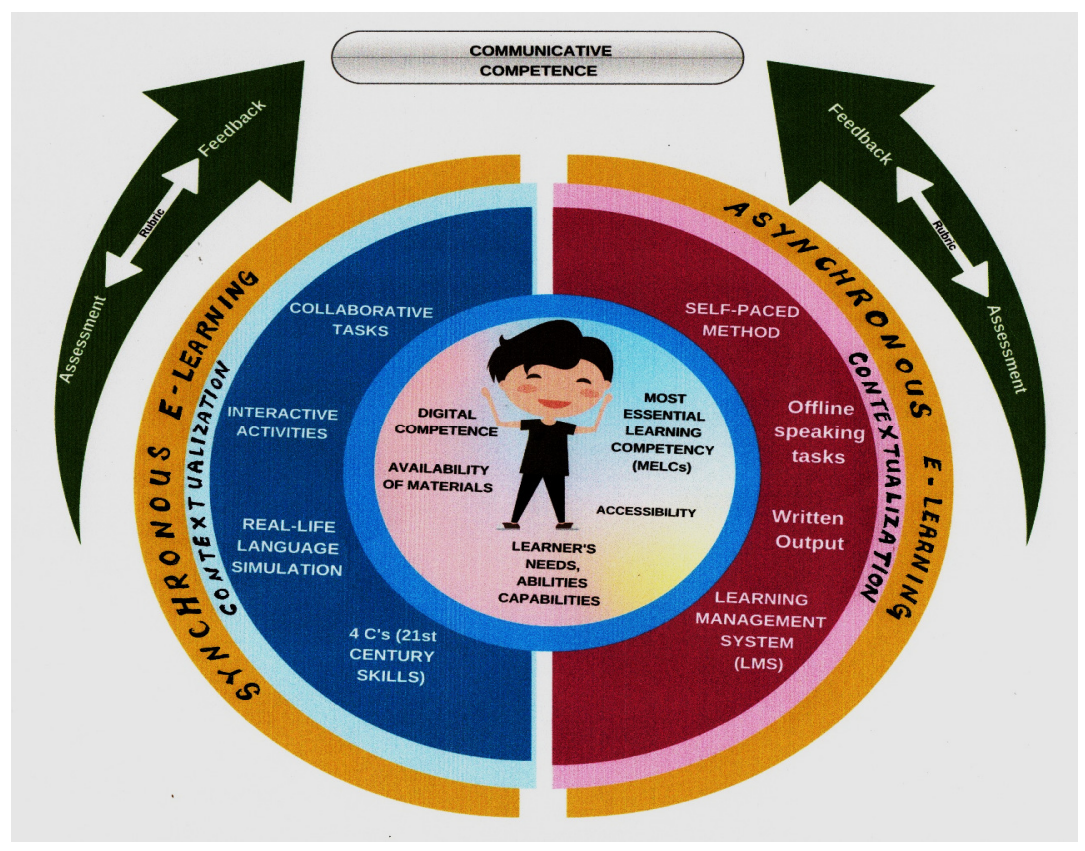

Figure 2. Online Distance Learning (ODL) Language Teaching Framework 
The proposed Online Distance Learning (ODL) Language Teaching Framework was founded from two learning theories which are the Constructivism and Metacognition. Sharma \& Poonam (2016) defined Constructivism as an innovative strategy which enable the learners to construct their knowledge themselves through interaction with each-other on the basis of previous experiences. In e-language learning, interactive and collaborative activities during synchronous session are highly encouraged. Also, the 4C's (Communication, Collaboration, Critical Thinking and Creativity) of $21^{\text {st }}$ Century Skills highlighted the demand for interactive and collaborative learning activities as it helps the learners to learn life-long skills vital not only to education but also in divergent professions.

In particular, interactive e-learning activities make synchronous language learning more engaging and fun which stimulates extrinsic motivation among learners. On the other hand, collaborative e-learning activities develop Higher Order Thinking Skills (HOTS), oral communication, student retention and confidence. In addition, it exposes the learner to diverse perspectives which provide him/her a profound meaning of language function. Subsequently, exposure to e-language learning environment will unconsciously develop the language use, grammar construction, syntax, pragmatics, comprehension and discourse. Meanwhile, Chick (2013) reiterated that Metacognition is, put simply, thinking about one's thinking. Founded with this theory, teachers are guided with principle to focus on the 'why' of learning aside from the 'how. In this way they can increase learner's intrinsic motivation. Self-regulation is being developed among themselves once they understand the purpose of language learning.

ODL Language Teaching Framework highlighted the importance of Metacognition in Asynchronous e-learning. Specifically, implementation of self-paced method is highly recommended for it will serve as the scaffold of e-language teaching-learning process. But focusing of Metacognition in language learning, they should be motivated by the way teachers prepare the asynchronous materials and activities. Common asynchronous e-learning activities to develop communicative competence are offline speaking tasks such as recorded interview and recorded speech which will encourage the learners to practice the English language even at her own pace. These offline speaking activities not just improve pronunciation but also develop discourse as well as language form and its appropriate contextual use. Contrary, written outputs which refers to written assessment tasks enables the learners to develop communicative competence in written form. Utilization of different written activities such as writing essay, analytical analysis, writing reflective journals, crafting story map, pen-and-paper test in grammar and discourse is employed.

In online distance learning, teachers as designer and implementer of the course curriculum should carefully plan the e-learning activities and assessments taking into consideration the needs, ability and capabilities of the learner. It is founded on the principle of Contextualization. It makes the lesson meaningful and relevant to the students' lives. It supports the idea of providing real-life situation to the learners as they are able to gage in their current situations in the lesson. Other considerations in designing e-language learning activities are learner's the digital competence, accessibility and availability of materials and most importantly it's alignment to the Most Essential Learning Competencies (MELCs) stipulated in Department of Education Order No. 12, series of 2020 entitled 'Adoption of Basic Education Learning Continuity Plan for School Year 2020-2021 in Light of the COVID-19 Public Health Emergency'.

Furthermore, the framework emphasizes the utilization of Rubrics in assessing the learner's communicative performance. In both synchronous and asynchronous e-learning, the objectivity of the assessment result could be realistically obtained through the use of rubrics which content indicators vary on what competency is being developed. In language perspective, the indicators focusing on developing grammatical, linguistic, sociolinguistic, discourse and strategic competencies should be incorporated to achieve the communicative competence underneath the Most Essential Learning Competency (MELCs) which are mandated by DepEd. As language advocate, teachers should always provide venue for language fluency and communicative competence mastery. 
In conclusion, ODL Language Teaching Framework in the new normal could be a positive teaching framework to develop learners' communicative competence as a whole. This can help the English teachers to appropriately plan and design their e-language activities in order to acquire the expected competencies along with the divergent factors present in online distance learning. If the teachers are properly funneled with what lies beyond e-language teaching, they can craft and implement e-language activities that will elevate learner's communicative competence. Putol

\section{Summary of Findings, Conclusions/Reflections and Directions for Future Use}

\subsection{Summary of Findings}

Based on the data gathered and after cautious and comprehensive analysis of the investigation, the following are the findings of the study in summarized form. The Level of Manifestation of Teaching Strategies of the English Teachers in Developing the Communicative Competence of the Grade 11 Learners as assessed by Master Teachers and Grade 11 English Teachers in the District of Silang, Division of Cavite in terms of Synchronous E-Learning is 3.71 and interpreted as Fully Manifested. Meanwhile, Asynchronous E-Learning has a general assessment of 3.61 and interpreted as Fully Manifested.

For the qualitative aspect of Synchronous E-Learning, two themes transpire. First, Theme 1: Real-Time Communicative E-Learning Activities which notes that the teacher participants provide learners with real-time communicative activities which promotes hands on English language practice to elevate learner's communicative competence. Particularly, this theme has subordinate themes which are: a) Interactive and Collaborative Activities as Product and Performance Task; b) Real-life Situation Activities as Language Simulation; and c) $21^{\text {st }}$ Century Skills as Communicative Competence' Scaffold. Second, Theme 2: Rubrics as Effective Communicative Assessment Tool which annotates the essential role of rubrics in assessing the communicative competence of the learners in online distance learning.

On the other hand, the qualitative aspect of Asynchronous E-Learning emerge two themes which are: Theme 1: Self-Paced Method as Communicative Assessment Tool which marks the teacher participants shared practices on the implementation of Self-paced Method in developing learner's communicative competence in asynchronous e-learning; and Theme 2: Learner's Capability as Center of E-Learning Endeavors which illuminates the their experiences on taking into consideration the learner's capabilities in designing the asynchronous e-learning activities. Moreover, the findings reveal that there is significant difference between the assessments of the Master Teachers and Grade 11 English teachers as regards the level of manifestation of the teaching strategies in developing communicative competence. Furthermore, a total of 379 learners or $84.22 \%$ of the learners who took the examination has developed their communicative competence in terms of grammatical competence while 71 learners or $15.78 \%$ did not meet the expectation. Meanwhile, a total of 214 learners or $47.56 \%$ of the learners who took the examination has developed their communicative competence in terms of discourse while 236 learners or $52.44 \%$ did not meet the expectation.

The study finds out that there is no significant relationship between the level of manifestation of teaching strategies and the level of Grade 11 learners' level of communicative competence. As shown in their probability values of $.716, .131, .173$ and .324 respectively, these are all greater than the level of significance at .05. Hence, the null hypothesis was accepted. Subsequently, there are problems encountered by the participants in online distance learning. In synchronous e-learning, two themes emerge, regarding problems encountered by the teacher participants, which are: 1) Low Level of Learners' Participation which may be due to various factors such as inappropriate e-learning activities, unconducive learning environment, incapability of learner's gadgets or accessibility, insufficient technological skills or even lack of motivation; and 2) Poor Learner's Attendance because of learner's lenient necessitate to attend synchronous session as pertinent to DepEd Order No.12, s. 2020 . 
A study on teaching strategies and communicative competence in online distance learning among grade 11

Meanwhile, the responses of the teacher participants regarding the problems they encounter in asynchronous e-learning in developing communicative competence include: 1) Lack of Digital Literacy which elucidates that both teachers and learners lack digital competence to manipulate technology-based instruction and activities effectively; 2) Late Submission of Output which may be due to procrastination because several studies showed that the absence of teacher in asynchronous e-learning gives the feeling of isolation to learners resulting to decrease in learner's motivation; 3) Plagiarism which is the most prevalent act of dishonesty observable in asynchronous e-learning wherein learners are trapped to "copy-and-paste" notion; 4) Provision of Immediate Feedback which may be due to various behavioral and technical predicaments which affect the submission of the learners' outputs and the teacher's provision of timely and constructive feedback that influence the development of learner's communicative competence; and 5) Grammatical and Syntactical Problem which heightened that some of the common grammatical errors identified in asynchronous e-learning includes errors in subject-verb-agreement, verb tense, noun, preposition, adjective, article, pronoun, adverbs and conjunctions. Also, learners' syntactical problem is detectable in the construction of run-on sentences due to improper punctuation, improper use of prepositions and conjunctions and apostrophe in word contraction. As an output, an ODL Language Teaching Framework is proposed for the English teachers in developing communicative competence in online distance learning to serve as a guide in designing effective communicative e-learning activities.

\subsection{Conclusions/Reflections}

Based on the aforementioned findings of the study, the following conclusions were derived.

First, the utilization of Rubrics is evidently done by the English teachers in assessing the Grade 11 learners' communicative competence in synchronous and asynchronous e-learning. Meanwhile, self-paced method is implemented in asynchronous e-learning as evident in the provision of offline speaking tasks and written outputs. In addition, most of English teachers formulate learning objectives as regards the students' accomplishment of tasks and activities based on the discussed topic/ lesson during the online session and provides the students to individually learn through self-paced method guided by clear and accurate instructions/directions.

Next, synchronous and asynchronous e-learning is evidently utilized in developing the communicative competence in online distance learning as assessed by Master teachers and English teachers. Subsequently, Grade 11 learners have developed their grammatical competence in Online Distance Learning. In the contrary, their discourse competence is not fully acquired in the said modality. Also, the teaching strategies in online distance learning have nothing to do with the Grade 11 learners' level of communicative competence.

Furthermore, incorrect grammar construction, syntax formation and poor reading comprehension are the common problems encountered by the English teachers in developing communicative competence. Likewise, submission of output, plagiarized output, failure to provide immediate feedback and learner's low level of participation are some of the challenges experienced in online distance learning.

Lastly, the proposed ODL Language Teaching Framework is necessary and can be an efficient tool to guide the English teachers in designing effective communicative e-learning activities.

\subsection{Recommendations}

Based on the findings summarized and conclusion drawn, the following recommendations are hereby offered. Initially, English teachers may upskill themselves as regards the various educational platforms to effectively utilize the data-based materials available in DepEd mandated Learning Management System (LMS). They may innovate assessment tools which focus not just on grammatical competence but also on other areas of grammatical competence such as linguistic competence, socio-linguistic competence, discourse competence and strategic competence. In connection with the latter recommendation, English teacher may also formulate rubrics which are appropriately designed to assess each aspect of communicative competence. In addition, Learner's 
Calma, R.

motivation, needs and capabilities should be on topmost considerations in the planning and implementation of the lesson in developing communicative competence.

Correspondingly, challenges with regard to the implementation of online learning should be properly addressed by the higher authority to include in the considerations of establishing e-language curriculum prevalent to the current educational system. Since there are underlying factors observed in developing communicative competence in online distance learning, English teachers may utilize the proposed ODL Language Teaching Framework in designing their e-language learning classroom. Future researchers may innovate other e-language framework to develop communicative competence of Grade 11 learners in online distance learning.

\section{References}

Ahmed, S., \& Pawar, S. (2018). Communicative competence in English as a Foreign Language: Its meaning and the pedagogical considerations for its development. Vol. II. 301 - 312. Aden University.

Amir, L. R., Tanti, I., Maharani, D. A., et al. (2020). Student perspective of classroom and distance learning during COVID-19 pandemic in the undergraduate dental study program Universitas Indonesia. BMC Med Educ, 20, 392. https://doi.org/10.1186/s12909-020-02312-0

Bhandari, B. L. (2021). English teachers' perspectives on classroom interaction: A phenomenological study [Blog article]. ELT CHOUTARI. Retrieved from http://eltchoutari.com/2021/01/english-teachers-perspectives-on-classroom-interaction-a-phenomenolog ical-study/

DepEd Order No.12, s. 2020. Adoption of Basic Education Learning Continuity Plan for School Year 2020-2021 in Light of the COVID-19 Public Health Emergency. Philippines: Department of Education.

DepEd Order No.21, s. 2019. Guidelines on the K to 12 Basic Education Program. Philippines: Department of Education.

Huang, X. (2018). Improving communicative competence through synchronous communication in computer-supported collaborative learning environments: A systematic review. Education Sciences. 8(15). https://doi.org/10.3390/educsci8010015

Islam, M. (2019). A critical reflection of constructivist teaching in CLT at higher secondary education in Bangladesh. i-manager's Journal on English Language Teaching, 9. https://doi.org/10.26634/jelt.9.4.16006

Khasanova, A. N. (2017). Use of internet technologies for students' communicative competence development in the process of professional foreign language. https://doi.org/10.1063/1.4972445

Pwarno, A. (2018). Constructivist learning theory: The contribution to Foreign Language learning and teaching. Retrieved from https://knepublishing.com/index.php/KnE-Social/article/view/1921/4298

Song, D., Rice, M., \& Oh, E.Y. (2019). Participation in online courses and interaction with a virtual agent. Athabasca University. Retrieved from http://www.irrodl.org/index.php/irrodl/article/view/3998/4952 https://doi.org/10.19173/irrodl.v20i1.3998 